\title{
Determination of Optical Constants of Nanocluster CdO Thin Films Deposited by Sol-Gel Technique
}

\author{
Z. Serbetci ${ }^{a}$, B. Gunduz ${ }^{b}$, A.A. Al-Ghamdi ${ }^{c}$, F. Al-Hazmic ${ }^{c}$, K. Arik $^{a}$, \\ F. El-TANTAWY ${ }^{d}$, F. YAKUPHANOGLU ${ }^{c, e, *}$ AND W.A. FAROOQ ${ }^{f}$ \\ ${ }^{a}$ Department of Chemistry, Faculty of Arts and Sciences, Bingol University, Bingol, Turkey \\ ${ }^{b}$ Department of Science Education, Faculty of Education, Muş Alparslan University, 49100 Muş, Turkey \\ ${ }^{c}$ Department of Physics, Faculty of Science, King Abdulaziz University, Jeddah 21589, Saudi Arabia \\ ${ }^{d}$ Department of Physics, Faculty of Science, Suez Canal University, Ismailia, Egypt \\ ${ }^{e}$ Department of Physics, Faculty of Science, Firat University, Elazig 23169, Turkey \\ ${ }^{f}$ Department of Physics and Astronomy, College of Science, King Saud University, Riyadh, Saudi Arabia
}

(Received January 19, 2014; in final form July 3, 2014)

The optical properties of the $\mathrm{CdO}$ and $\mathrm{Pt}$ doped $\mathrm{CdO}$ thin films synthesized by sol-gel technique were investigated. The lowest grain size value $(81.34 \mathrm{~nm})$ was found to be for $\mathrm{CdO}$ thin film. The Pt doped CdO films are transformed to clusters with nanoparticles. The transparency properties of the CdO thin film is changed with $\mathrm{Pt}$ doping. The plots of refractive index indicate abnormal and normal dispersion regions. The refractive index values of the $\mathrm{CdO}$ thin film are changed with Pt doping. The direct optical band gap values of the films were changed with doping of Pt. The film of $0.5 \% \mathrm{Pt}$ doped $\mathrm{CdO}$ indicates the lowest optical band gap value $(2.421 \mathrm{eV})$. The imaginary parts of the optical conductivity of the $\mathrm{CdO}$ and $\mathrm{Pt}$ doped $\mathrm{CdO}$ thin films are higher than that of the real parts of the optical conductivity.

DOI: 10.12693 /APhysPolA.126.798

PACS: 78.67.Bf, 78.20.Ci, 81.20.Fw

\section{Introduction}

In recent years, there have been many works on the production and investigation of the physical properties of transparent conducting oxide (TCO) materials due to their electrical and optical properties such as low resistivity and high optical transmittance [1-5]. The first report of a TCO was published in 1907, when Badeker reported that thin films of $\mathrm{Cd}$ metal deposited in a glow discharge chamber could be oxidized to become transparent while remaining electrically conducting [5]. Since then, the commercial value of TCO thin films has been recognized [5], and the list of potential TCO materials has expanded with doping of various materials [6]. TCOs have great importance in the semiconductor, electronic and optoelectronic devices [7]. Thin films of $n$-type transparent conducting oxides ( $n$-TCOs) such as zinc oxide $(\mathrm{ZnO})$ [8], cadmium oxide $(\mathrm{CdO})$ [9-11], indium oxide $\left(\mathrm{In}_{2} \mathrm{O}_{3}\right)$ [12], tin oxide $\left(\mathrm{SnO}_{2}\right)$ [13], indium tin oxide (ITO) [14] and $p$-type transparent conducting oxides ( $p$-TCOs) such as $\mathrm{CuAlO}_{2}[15,16], \mathrm{SrCu}_{2} \mathrm{O}_{2}$ [17], tingallium oxide [18], etc. have received considerable attention mainly due to their important potential applications, which include photovoltaic solar cells, gas sensors, transparent electrodes, and other optoelectronic devices [7].

TCO thin films such as $\mathrm{ZnO}, \mathrm{InO}, \mathrm{SnO}_{2}$, ITO and $\mathrm{CdO}$ have attracted considerable attention because of

${ }^{*}$ corresponding author; e-mail: fyhanoglu@firat.edu.tr their low resistivity and high optical transmittance [1-5]. TCOs are used due to their optical, sensitive to light and electrical properties, for photodiodes, solar cells, smart windows, flat panel display and light emitting, surface acoustic wave device, varistors, photovoltaic materials, liquid crystal displays, gas sensors, transparent conducting electrodes, phototransistors, optical heaters etc. other optoelectronic applications $[6,19-27]$. The high conductivity of TCO films results mainly from stoichiometric deviation. The conduction electrons in the TCO films are supplied from donor sites associated with oxygen vacancies or excess metal ions [28]. The oxide is insoluble in water, absorbs $\mathrm{CO}_{2}$ from air and can be reduced to the conducting oxides which have received very little attention; though it is one of the promising candidate for optoelectronic field [5, 29-31].

Among different TCOs, $\mathrm{CdO}$ is considered as a promising material for photovoltaic applications due to its high electrical conductivity and optical transmittance in the visible region of solar spectrum [32] and $\mathrm{CdO}$ is particularly interesting due to its low resistivity and high carrier concentration, which endows it great potential for using in optoelectronic devices [6, 33, 34]. CdO based TCOs are of great interest due to their metal like charge transport behavior with an exceptionally large carrier mobility and good optical transparency in the visible region [35-37]. The CdO has special features such as high conductivity, high transmission, and low band gap which made it applicable in photodiodes, solar cells, flat panel displays, smart windows, optical communications, thin-film resistors, phototransistors, photovoltaics, transpar- 
ent conducting electrodes, liquid crystal displays, IR detectors, and antireflecting coatings [5, 30, 31, 38]. Due to its low optical band gap, non-stoichiometric undoped $\mathrm{CdO}$ is not widely used in optoelectronics and photovoltaics, although $\mathrm{CdO}$ thin films show low resistivity due to defects of oxygen vacancies and cadmium interstitials [24, 34]. $\mathrm{CdO}$ is an $n$-type semiconductor with a $\mathrm{NaCl}$ (a rock-salt crystal structure (fcc)) structure [27] and band gap values of $2.5 \mathrm{eV}$ [39], 2.2-2.8 eV [40-42], $2.16 \mathrm{eV}$ [40], 2.2-2.4 eV [43], between 2.2 and $2.7 \mathrm{eV}$ $[8,41,44,45]$ and has a direct energy band gap of $2.2 \mathrm{eV}$ [46, 47], in-between 2.2 and $2.7 \mathrm{eV}[8,24,41,45,48]$, narrow energy band gap energy $(2.6 \mathrm{eV}$ and $2.1 \mathrm{eV}$ direct and indirect band gap, respectively) [48], direct band gap of $2.5 \mathrm{eV}$, indirect band gap of $2.1 \mathrm{eV}$ [48], two indirect bandgaps at 1.18-1.2 eV and 0.8-1.12 eV [8, 24, 41, 45, 48] and a relatively low intrinsic band gap of $2.3 \mathrm{eV} \mathrm{[49]} \mathrm{and}$

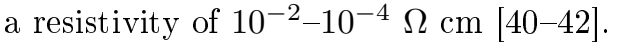

Theoretically, it was established that $\mathrm{CdO}$ has a direct band gap of $2.18 \mathrm{eV}$ [45] or $2.38 \mathrm{eV}$ [50] and two indirect band gaps of $0.8 \mathrm{eV}$ and $1.2 \mathrm{eV}$ [51] or $0.95 \mathrm{eV}$ and $1.11 \mathrm{eV}$ [52], or $1.12 \mathrm{eV}$ and $1.18 \mathrm{eV}$ [53]. The $n$-type conduction of undoped $\mathrm{CdO}$ was attributed to its native oxygen vacancies and cadmium interstitials [54]. CdO shows very high electrical conductivity even without doping due to the existence of shallow donors caused by intrinsic interstitial cadmium atoms and oxygen vacancies $[1,46]$. $\mathrm{CdO}$ films are transparent in visible and near infrared (NIR) spectral regions and have an electrical resistivity of $10^{-2}-10^{-4} \Omega \mathrm{cm}$ [44].

Researchers are trying to modify the synthesis procedure for $\mathrm{CdO}$ thin films with the aim to improve chemical and physical properties of this material and try to synthesize nanostructures with well defined geometrical shapes (e.g., spheres, cubes, rods, wires, tubes, tetrapods, ribbons, disks, and platelets). Researchers effort to organize them as 2- and 3-dimensional assemblies has further expanded the possibility of developing new strategies for light energy conversion. The first six shapes are being intensively studied for renewable energy applications [55-57]. CdO thin films have great technological interest due to their high-quality electrical and optical properties [58]. Doped CdO films, as multi component oxides films constituted of $\mathrm{CdO}$, have been used in several applications: photovoltaic devices [59, 60], gas sensors [61], phototransistors and diodes [62], etc.

Different physical and chemical deposition methods have been employed to prepare undoped $\mathrm{CdO}$ and doped $\mathrm{CdO}$ films such as ion beam sputtering, successive ionic layer adsorption and reaction (SILAR), thermal evaporation, metal organic chemical vapor deposition (MOCVD), sputtering, electron beam evaporation and sol-gel, spray pyrolysis, dc magnetron sputtering, radio frequency (rf) sputtering, chemical bath deposition, pulsed laser deposition (PLD) etc. [7, 33, 42, 63-71]. Among these methods of preparation of pure and doped $\mathrm{CdO}$, the sol-gel technique is one of the most promising tools in material science and it is one of the most promis- ing available methods for synthesizing nanoparticles of controlled size and morphology [72]. The sol-gel spin coating method has various advantages such as cost effectiveness, thin, transparent, multicomponent oxide layers of many compositions on various substrates, simplicity, excellent compositional control, homogeneity and lower crystallization temperature [28]. Also, it does not require vacuum apparatus and has the potential to produce films with large areas on various substrates [73]. The synthetic route provided by this system is the most feasible one for designing materials possessing unique properties. Generally, it is a process concerning transition of a system from liquid "sol" (the colloidal suspension of particles) into solid "gel" [72].

However, there are few works reported in the literature with respect to $\mathrm{CdO}$ films obtained by the sol-gel technique, a fact rather surprising due to these excellent advantages that the sol-gel technique presents [48]. The optical properties and thus the band gap of $\mathrm{CdO}$ can also be controlled by doping [74]. Some researchers reported that $\mathrm{CdO}$ films can be doped with $\mathrm{Sc}, \mathrm{Y}, \mathrm{Sm}, \mathrm{Mn}, \mathrm{Sn}$, $\mathrm{Mg}, \mathrm{Cu}, \mathrm{F}, \mathrm{In}, \mathrm{Ga}, \mathrm{Al}, \mathrm{Fe}, \mathrm{Cd}, \mathrm{Zn}, \mathrm{Ti}, \mathrm{Dy}$, etc. [27, 33, $39,54,58,67,71,75-77]$ and they have been used in several applications: photovoltaic devices, gas sensors, phototransistors, and diodes, etc. [58, 67]. It is found that the doping of $\mathrm{In}, \mathrm{Ti}, \mathrm{Al}$ enhances $E_{\mathrm{g}}$ to $2.74-2.84 \mathrm{eV}$ and simultaneously increases the electrical conductivity [27, 34, 39]. Maity and Chattopadhyay [78] have reported that the band gap of $\mathrm{CdO}$ can be reduced by $\mathrm{Al}$ doping, whereas Deokate et al. [79] have reported that F doping increases the optical band gap of pure $\mathrm{CdO}$ films. It was observed that the band gap of the $\mathrm{CdO}$ film decreases from 2.76 to $2.36 \mathrm{eV}$ due to increase in the $\mathrm{Al}$ percentage from 1.32 to 7.24 . Yakuphanoglu [80] reported that the electrical, structural and optical properties of $\mathrm{CdO}$ films could be controlled by boron dopant for electronic and photovoltaic applications.

Recently, Dakhel $[76,81,82]$ has published a few papers based on rare earth element doped $\mathrm{CdO}$ films. It is reported in these papers that the optical band gap of the $\mathrm{CdO}$ films in general decreases due to light doping of rare earth elements [74]. Gupta et al. reported the effect of growth parameters on structural, optical, and electrical properties of $\mathrm{Ti}, \mathrm{Sn}, \mathrm{Al}$ doped $\mathrm{CdO}$ thin films by pulse laser deposition technique [83-86]. Martin et al. [87] have deposited multilayer of TCOs using Sn doped $\mathrm{CdO}$ and $\mathrm{Sn}$ doped $\mathrm{CdIn}_{2} \mathrm{O}_{4}$ using pulsed laser deposition technique. It was found that doping of $\mathrm{CdO}$ with ions of a smaller ionic radius than that of $\mathrm{Cd}^{2+}$, like In, $\mathrm{Sn}, \mathrm{Al}, \mathrm{Sc}$, and Y improved its electrical conductivity and increased its optical energy gap, which was explained by application of Moss-Burstein (B-M) effect [11, 24, 75, 78, 82, 88, 89]. Gupta et al. [74] reported that the bandgap of the $\mathrm{CdO}$ film is decreased by $\mathrm{Cu}$ doping and among the $\mathrm{Cu}$ doped $\mathrm{CdO}$ films, the bandgap was observed to increase with increase in copper doping level.

Furthermore, some scientists made many researches on optical properties on the pure $\mathrm{CdO}$ and doped $\mathrm{CdO}$ thin 
films. Yakuphanoglu [90] reported that the transparency of the nanocluster-CdO film lies in the range of $70-80 \%$ in the visible range and it reaches a $92 \%$ value in the visible range and with its optical band gap $E_{\mathrm{g}}$ of $2.27 \mathrm{eV}$. Dakhel [91] reported that the $\mathrm{CdO}$ and Tl-doped $\mathrm{CdO}$ films with the optical energy band values of $2.308 \mathrm{eV}$ and $2.721 \mathrm{eV}$, respectively. Kose et al. [1] reported that the $\mathrm{CdO}$ and In-doped $\mathrm{CdO}$ films with the optical band gap values of $2.51,2.49,2.62$ and $2.78 \mathrm{eV}$, the refractive index values of $4.39,3.86,2.93$ and 2.05 at $\lambda=600 \mathrm{~nm}$ for pure $\mathrm{CdO}, 1 \%, 3 \%$, and $5 \%$ In-doped CdO films, respectively. Gupta et al. [74] reported the $\mathrm{CdO}$ and $\mathrm{Cu}$-doped $\mathrm{CdO}$ films with the optical band gap values of $2.57,2.41$, $2.47,2.49$ and $2.52 \mathrm{eV}$ for pure $\mathrm{CdO}, 1 \%, 2 \%, 3 \%$ and $4 \% \mathrm{Cu}$-doped $\mathrm{CdO}$ films, respectively. Yakuphanoglu et al. [28] reported the $\mathrm{CdO}$ films with the optical band gap of $2.45 \mathrm{eV}$. Dakhel [54] reported the $\mathrm{CdO}$ and $\mathrm{Ga}-$ -doped $\mathrm{CdO}$ films with the optical band gap values of 2.16, 2.22, 3.70 and $2.17 \mathrm{eV}$ for pure $\mathrm{CdO}, 3 \%, 6 \%$ and $9 \%$ Ga doped $\mathrm{CdO}$ films, respectively. Zheng et al. [34] reported the $\mathrm{CdO}$ and $\mathrm{Sn}$-doped $\mathrm{CdO}$ films with the optical band gap values of 2.40 and $2.82-2.93 \mathrm{eV}$ for pure $\mathrm{CdO}$ and $\mathrm{Sn}-\mathrm{CdO}$ thin films, respectively. Yakuphanoglu [80] reported the $\mathrm{CdO}$ and boron-doped $\mathrm{CdO}$ thin films with the optical band gap values of $2.27,2.17,2.45,2.29$ and $2.24 \mathrm{eV}$, the dispersion energy values of $7.17,1.85$, $27.55,5.34$ and $7.01 \mathrm{eV}$, the average excitation energy values of $3.79,3.03,12.03,3.31$ and $4.74 \mathrm{eV}$, an average oscillator wavelength values of $327.7,409.9,103.2$, 375.2 and $262 \mathrm{~nm}$, the average oscillator strength values of $1.75 \times 10^{13}, 3.64 \times 10^{12}, 2.13 \times 10^{13}, 1.13 \times 10^{13}$ and $2.13 \times 10^{13} \mathrm{~m}^{-2}$ for pure $\mathrm{CdO}$ and $1 \%, 5 \%, 10 \%$ and $15 \%$ B doped CdO thin films, respectively. Santos-Cruz et al. [70] reported the $\mathrm{CdO}$ and fluorine (F)-doped $\mathrm{CdO}$ films with the optical band gap values of about 2.65, 2.70, 2.77, and $2.82 \mathrm{eV}$ for pure $\mathrm{CdO}$ and $1 \%, 5 \%$, and $20 \% \mathrm{~F}$-doped $\mathrm{CdO}$ thin films, respectively.

In this work we have employed sol-gel technique to prepare platinum $(\mathrm{Pt})$ doped $\mathrm{CdO}$. There is no any report on the preparation, surface morphology and optical properties of $\mathrm{Pt}$ doped cadmium oxide thin films by sol-gel technique. In this study, we have studied in detail the surface morphology and optical properties of the pure $\mathrm{CdO}$ and $\mathrm{Pt}$ doped $\mathrm{CdO}$ thin films synthesized by sol-gel technique which is a very simple and economical method.

\section{Experimental details}

Thin films of platinate doped $\mathrm{CdO}$ were fabricated using the sol-gel technique. Cadmium acetate dehydrate $\left(\mathrm{C}_{4} \mathrm{H}_{6} \mathrm{CdO}_{4} 2\left(\mathrm{H}_{2} \mathrm{O}\right)\right)$, potassium hexachloroplatinate(IV) (Pt), 2-metoxyethanol and monoethanolamine were used for fabrication of $\mathrm{CdO}$ and $\mathrm{Pt}$ doped $\mathrm{CdO}$ films. The required chemicals were purchased from Alfa Aesar and were used without further purification. In a typical synthesis, $0.5 \mathrm{M}$ of cadmium acetate dehydrate was slowly dissolved in 2-metoxyethanol followed by addition of monoethanolamine. The molar ratio of monoethanolamine to cadmium acetate was 1.0. For $\mathrm{Pt}$ doped $\mathrm{CdO}$, the required amount of potassium hexachloroplatinate was added in the above mixture to get $0.1 \%, 0.5 \%, 1 \%$ and $2 \%$ of $\mathrm{Pt}$ doped $\mathrm{CdO}$. The prepared mixtures were stirred using a magnetic stirrer at $60^{\circ} \mathrm{C}$ for about 30 min to obtain clear homogeneous solution and then the sol was kept for aging for $4 \mathrm{~h}$ before the film deposition. The pure $\mathrm{CdO}$ and $\mathrm{Pt}$ doped $\mathrm{CdO}$ films were deposited on microscopy glasses at $1500 \mathrm{rpm}$ for $30 \mathrm{~s}$ by the sol-gel spin coating method. After the spin coating, the films were dried at $150^{\circ} \mathrm{C}$ for $5 \mathrm{~min}$ to evaporate the solvent and remove organic residuals. This coating/drying procedure was repeated for eight times. Then, the prepared undoped and $\mathrm{Pt}$ doped $\mathrm{CdO}$ films were annealed at $400^{\circ} \mathrm{C}$ for $1 \mathrm{~h}$ in a furnace. Surface morphology was investigated by PARK system XE100E atomic force microscopy (AFM). The absorbance, transmittance and reflectance properties of the films were taken using a Shimadzu UV-vis-NIR3600 spectrophotometer.

\section{Results and discussion}

\subsection{Surface morphology properties of Pt-doped CdO films}

$\mathrm{X}$-ray diffraction patterns of $\mathrm{Pt}$-doped $\mathrm{CdO}$ films are shown in Fig. 1a. It is evaluated that undoped $\mathrm{CdO}$ and $\mathrm{Pt}$ doped $\mathrm{CdO}$ films have the cubic $\mathrm{NaCl}$ structure with the lattice parameters of undoped $\mathrm{CdO}$ consented with JCPDS data [92]. The obtained results suggest that [111] direction is the direction preferred orientation growth. This means that the $\mathrm{CdO}$ films are grown along this direction. The intensity of the (111) plane is changed with $\mathrm{Pt}$ content. This indicates that $\mathrm{Pt}$ ions substitutionally replaced $\mathrm{Cd}$ ions in the lattice.

The surface morphology properties of the active layers of the $\mathrm{CdO}$ and $\mathrm{Pt}$ doped $\mathrm{CdO}$ thin films were investigated using an AFM. The all images of the $\mathrm{CdO}$ thin film were taken in $5 \mu \mathrm{m} \times 5 \mu \mathrm{m}$ area. Figure $1 \mathrm{~b}-\mathrm{f}$ shows one-dimensional (1D) AFM images of the $\mathrm{CdO}$ and $\mathrm{Pt}$ doped $\mathrm{CdO}$ thin films for $5 \mu \mathrm{m} \times 5 \mu \mathrm{m}$ area. As seen in Fig. 1, the $\mathrm{CdO}, 0.5 \% \mathrm{Pt}-\mathrm{CdO}, 1 \% \mathrm{Pt}-\mathrm{CdO}$, and $2 \% \mathrm{Pt}-$ $\mathrm{CdO}$ thin film are formed from small crystal grains and $0.1 \% \mathrm{Pt}-\mathrm{CdO}$ thin film is formed from nanoclusters, with an almost homogeneous distribution.

\section{TABLE I}

The crystal grain/nanocluster size and surface roughness $R_{q}$ values of the $\mathrm{CdO}$ and $\mathrm{Pt}$ doped $\mathrm{CdO}$ thin films for $5 \mu \mathrm{m} \times 5 \mu \mathrm{m}$ area.

\begin{tabular}{c|c|c}
\hline \hline Thin films & $\begin{array}{c}\text { Grain/nanocluster } \\
\text { size }[\mathrm{nm}]\end{array}$ & $\begin{array}{c}\text { Surface roughness } \\
\left(R_{q}\right)[\mathrm{nm}]\end{array}$ \\
\hline pure CdO & 81.34 & 35.215 \\
$0.1 \% \mathrm{Pt}-\mathrm{CdO}$ & 816.5 & 128 \\
$0.5 \% \mathrm{Pt}-\mathrm{CdO}$ & 396.91 & 71.334 \\
$1 \% \mathrm{Pt}-\mathrm{CdO}$ & 373.9 & 71.562 \\
$2 \% \mathrm{Pt}-\mathrm{CdO}$ & 206.2 & 30.724
\end{tabular}



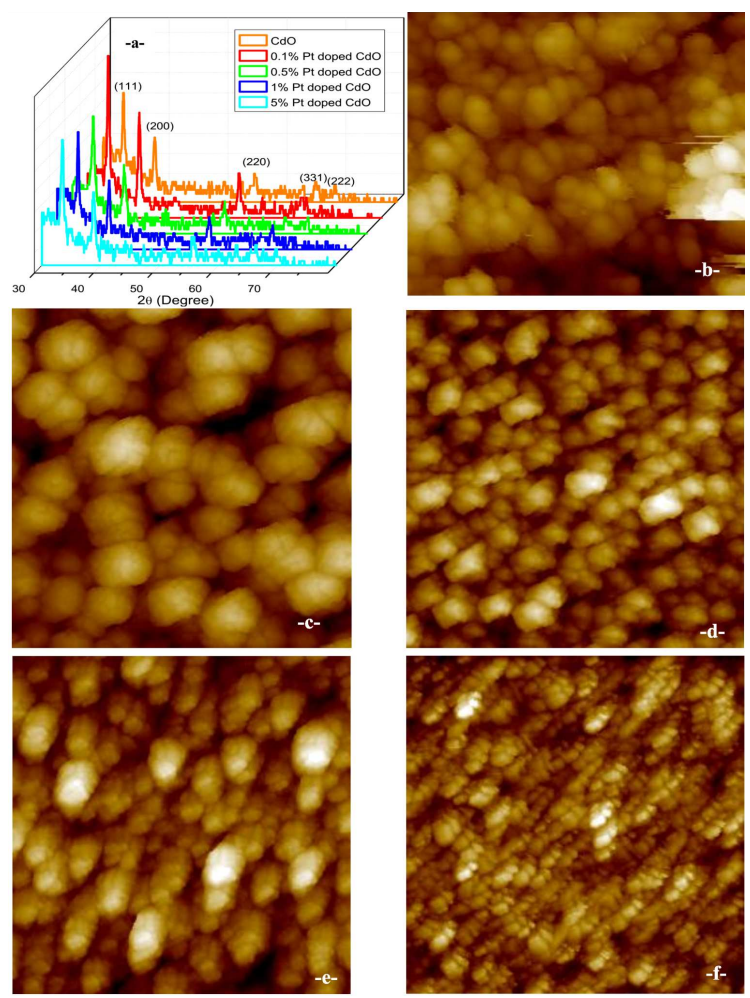

Fig. 1. One-dimensional (1D) AFM images of the (a) pure $\mathrm{CdO}$, (b) $0.1 \%$, (c) $0.5 \%$, (d) $1 \%$ and (e) $2 \% \mathrm{Pt}$ doped $\mathrm{CdO}$ thin film for $5 \mu \mathrm{m} \times 5 \mu \mathrm{m}$ area.

The small crystal grain and nanocluster size values of the $\mathrm{CdO}$ and $\mathrm{Pt}$ doped $\mathrm{CdO}$ thin films for $5 \mu \mathrm{m} \times 5 \mu \mathrm{m}$ area were determined and given in Table I. The surface roughness $R_{q}$ values of the $\mathrm{CdO}$ and $\mathrm{Pt}$ doped $\mathrm{CdO}$ thin films for $5 \mu \mathrm{m} \times 5 \mu \mathrm{m}$ area were determined from the all surfaces of the $\mathrm{CdO}$ and $\mathrm{Pt}$ doped $\mathrm{CdO}$ thin films using Park System XEI software programming and given in Table I. As seen in Table I, the average crystal grain size value $(81.34 \mathrm{~nm})$ of the $\mathrm{CdO}$ thin film is the lowest value of all the films, while the average crystal grain size value $(396.91 \mathrm{~nm})$ of the $0.5 \% \mathrm{Pt}-\mathrm{CdO}$ thin film is the highest value of all films. Also, the nanocluster size value of the $0.1 \% \mathrm{Pt}-\mathrm{CdO}$ thin film was found to be $816.5 \mathrm{~nm}$. It is observed that the small crystal grain size of the $\mathrm{CdO}$ thin film increases with doping of Pt. As seen in Table I, the $R_{q}$ value $(30.724 \mathrm{~nm})$ of the $2 \% \mathrm{Pt}-\mathrm{CdO}$ thin film is the lowest value of all the films, while the surface roughness $\left(R_{q}\right)$ value $(128 \mathrm{~nm})$ of the $0.1 \% \mathrm{Pt}-\mathrm{CdO}$ thin film is the highest value of all films. Therefore, the grain size and the surface roughness of the co-doped films could be controlled.

\subsection{Optical properties of Pt doped $\mathrm{CdO}$ thin films}

\subsubsection{Determination of refractive index parameters} of the $\mathrm{CdO}$ and Pt doped $\mathrm{CdO}$ thin films

The transmittance spectra of the $\mathrm{CdO}$ and $\mathrm{Pt}$ doped $\mathrm{CdO}$ thin films were measured to investigate their optical properties and they are shown in Fig. 2a. In the visible region, the average transmittance values of the $\mathrm{CdO}$ and $\mathrm{Pt}$ doped $\mathrm{CdO}$ thin films were calculated and given in Table II. As seen in Table II, the average transmittance $(71.316 \%)$ of the $\mathrm{CdO}$ thin film is the highest value, while the average transmittance $(50.461 \%)$ of the $0.5 \% \mathrm{Pt}-\mathrm{CdO}$ thin film is the lowest value of all the films. This value is close to value $(70-80 \%)$ of the transparency in the visible range in the literature [90]. As seen in Table II, the average transmittance value of the $\mathrm{CdO}$ thin film decreases with doping of Pt. To estimate the absorption band edge of the $\mathrm{CdO}$ and $\mathrm{Pt}$ doped $\mathrm{CdO}$ thin films, the first derivative of the optical transmittance can be computed. The curves of $\mathrm{d} T / \mathrm{d} \lambda$ versus wavelength were plotted, as shown in Fig. 2b. As seen in Fig. 2b, the maximum peak position corresponds to the absorption band edge and there is a small shift in the direction of the longer wavelengths. The absorption band edge values of the $\mathrm{CdO}$ and $\mathrm{Pt}$ doped $\mathrm{CdO}$ thin films were calculated from the maximum peak position and given in Table II. As seen in Table II, the maximum peak values of the $\mathrm{CdO}$ and $\mathrm{Pt}$ doped $\mathrm{CdO}$ thin films vary from 548.5 to $637.5 \mathrm{~nm}$. This suggests that the absorption band edge values of the $\mathrm{CdO}$ and $\mathrm{Pt}$ doped $\mathrm{CdO}$ thin films shift from 2.264 to $1.948 \mathrm{eV}$ with the doping of Pt. As seen in Table II, the absorption band edge of the $\mathrm{CdO}$ thin film decreases with doping of $\mathrm{Pt}$.

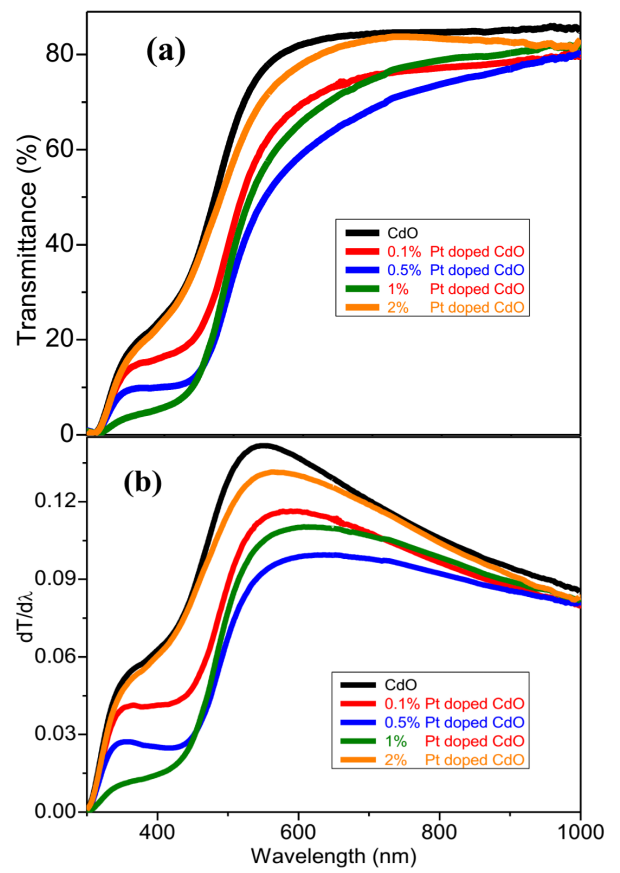

Fig. 2. (a) The transmittance spectra and (b) the curves of $\mathrm{d} T / \mathrm{d} \lambda$ versus wavelength of the $\mathrm{CdO}$ and $\mathrm{Pt}$ doped CdO thin films. 
Some important optical parameters of the $\mathrm{CdO}$ and $\mathrm{Pt}$ doped $\mathrm{CdO}$ thin films.

\begin{tabular}{c|c|c|c|c|c}
\hline \hline & Pure CdO & $0.1 \% \mathrm{Pt}-\mathrm{CdO}$ & $0.5 \% \mathrm{Pt}-\mathrm{CdO}$ & $1 \% \mathrm{Pt}-\mathrm{CdO}$ & $2 \% \mathrm{Pt}-\mathrm{CdO}$ \\
\hline average transmittance [\%] & 71.316 & 58.745 & 50.461 & 55.086 & 68.446 \\
maximum peak [nm] & 548.5 & 598 & 637.5 & 607 & 561.5 \\
absorption band edge [eV] & 2.264 & 2.077 & 1.948 & 2.046 & 2.212 \\
$E[\mathrm{eV}]$ & 2.835 & 2.782 & 2.695 & 2.829 & 3.670 \\
$E_{d}[\mathrm{eV}]$ & 1.648 & 3.678 & 4.733 & 2.869 & 2.363 \\
$E_{d} / E$ & 0.581 & 1.322 & 1.756 & 1.014 & 0.644 \\
$n_{\infty}$ & 1.343 & 1.846 & 1.974 & 1.702 & 1.211 \\
$\lambda[\mathrm{nm}]$ & 438.1 & 446.5 & 460.9 & 439.1 & 338.4 \\
$S\left[\mathrm{~m}^{-2}\right] \times 10^{12}$ & 4.074 & 12.08 & 13.64 & 9.838 & 4.187
\end{tabular}

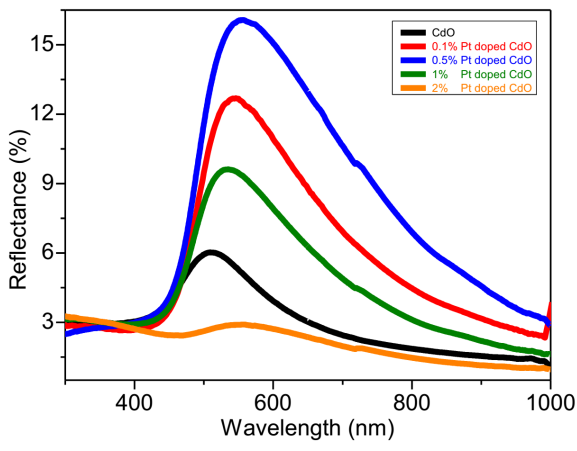

Fig. 3. The reflectance spectra of the $\mathrm{CdO}$ and $\mathrm{Pt}$ doped $\mathrm{CdO}$ thin films.

The reflectance spectra of the $\mathrm{CdO}$ and $\mathrm{Pt}$ doped $\mathrm{CdO}$ thin films is shown in Fig. 3. As seen in Fig. 3, reflectance spectra of the $\mathrm{CdO}$ thin films changes with doping of $\mathrm{Pt}$ and the reflectance spectra of the $0.5 \% \mathrm{Pt}-\mathrm{CdO}$ thin film is the highest value, while the reflectance spectra of the $2 \% \mathrm{Pt}-\mathrm{CdO}$ thin film is the lowest value of all the films.

The refractive index is an important parameter for optical applications. Thus, it is important to determine optical constants of the $\mathrm{CdO}$ and $\mathrm{Pt}$ doped $\mathrm{CdO}$ thin films and the complex optical refractive index of the films is expressed as

$$
\hat{n}=n(\omega)+\mathrm{i} k(\omega),
$$

where $n$ is the real part and $k$ is the imaginary part of complex refractive index. The optical properties of the films are characterized by refractive index. The refractive index of the films can be obtained from the following equation [93]:

$$
n=\left\{\left[\frac{4 R}{(R-1)^{2}}-k^{2}\right]^{1 / 2}-\frac{R+1}{R-1}\right\} .
$$

The refractive index values of the $\mathrm{CdO}$ and $\mathrm{Pt}$ doped $\mathrm{CdO}$ thin films were calculated from Eq. (2).

Figure 4 shows the refractive index plot vs. wavelength of the $\mathrm{CdO}$ and $\mathrm{Pt}$ doped $\mathrm{CdO}$ thin films. As seen in Fig. 4, plot of refractive index is composed of two regions so-called abnormal and normal dispersion. The $n$ values of the $\mathrm{CdO}$ and $\mathrm{Pt}$ doped $\mathrm{CdO}$ thin films increase with increasing $\lambda$ in abnormal dispersion region, while the re-

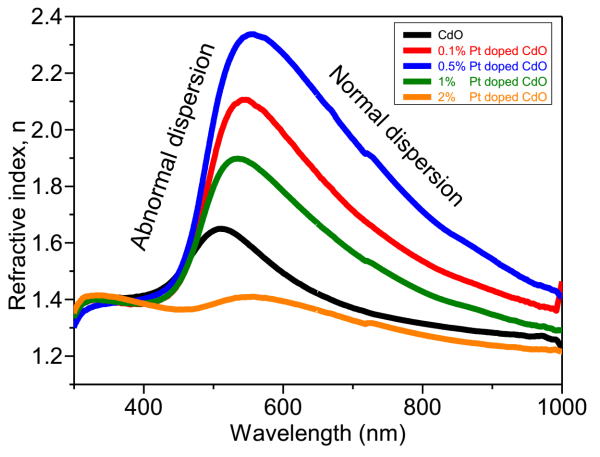

Fig. 4. The refractive index plot vs. wavelength of the $\mathrm{CdO}$ and $\mathrm{Pt}$ doped $\mathrm{CdO}$ thin films.

fractive index $(n)$ values of the $\mathrm{CdO}$ and $\mathrm{Pt}$ doped $\mathrm{CdO}$ thin films decrease with increasing wavelength in normal dispersion region. As seen in Fig. 4, the refractive index values of the $\mathrm{CdO}$ thin film change with doping of $\mathrm{Pt}$ and the refractive index of the $0.5 \% \mathrm{Pt}-\mathrm{CdO}$ thin film is the highest value, while the refractive index of the $2 \% \mathrm{Pt}-$ $\mathrm{CdO}$ thin film is the lowest value of all the films. This suggests that the refractive index of the $\mathrm{CdO}$ thin film can be both reduced and increased with doping of Pt. This is a very significant improvement for optical applications. The refractive index (2.269) of the $0.5 \% \mathrm{Pt}-\mathrm{CdO}$ thin film at $\lambda=600 \mathrm{~nm}$ is higher than that value (2.05) of the $5 \%$ In-doped $\mathrm{CdO}$ films at $\lambda=600 \mathrm{~nm}$ in the literature [1], but the refractive index values (between 2.93 and 4.39) of the $\mathrm{CdO}$ and In-doped $\mathrm{CdO}$ films at $\lambda=600 \mathrm{~nm}$ in the literature [1] is higher than that of the studied pure $\mathrm{CdO}, 0.1 \%, 1 \%$ and $2 \% \mathrm{Pt}-\mathrm{CdO}$ thin film at $\lambda=600 \mathrm{~nm}$

The refractive index dispersion in polymer can be analyzed using single oscillator model. The dispersion of the refractive index is expressed as [94]:

$$
n^{2}-1=\frac{E_{\mathrm{d}} E_{0}}{E_{0}^{2}-E^{2}},
$$

where $h$ is Planck's constant, $\nu$ is the frequency, $E$ is the photon energy, $E_{0}$ is the average excitation energy for electronic transitions, and $E_{\mathrm{d}}$ is the dispersion energy, which is a measure of the strength of inter band optical transitions. Experimental verification of Eq. (3) [single-oscillator model] can be obtained by plotting $1 /\left(n^{2}-1\right)$ 
vs. $E^{2}$. The resulting straight line yields values of the parameters $E_{0}$ and $E_{\mathrm{d}}$.

The plot $1 /\left(n^{2}-1\right)$ vs. $E^{2}$ of the $\mathrm{CdO}$ and Pt doped $\mathrm{CdO}$ thin films is shown in Fig. 5 .

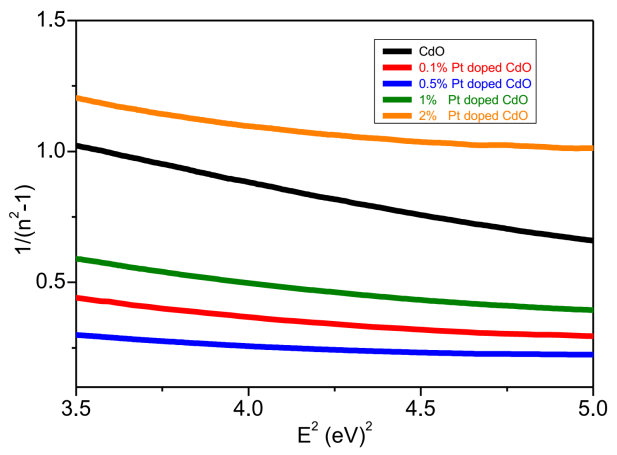

Fig. 5. The plot $1 /\left(n^{2}-1\right)$ vs. $E^{2}$ of the $\mathrm{CdO}$ and $\mathrm{Pt}$ doped CdO thin films.

The $E_{0}$ and $E_{\mathrm{d}}$ values of the $\mathrm{CdO}$ and $\mathrm{Pt}$ doped $\mathrm{CdO}$ thin films were calculated for normal dispersion regions of the films and given in Table II. As seen in Table II, the excitation and dispersion energy values of the $\mathrm{CdO}$ thin film change with doping of $\mathrm{Pt}$. The excitation energy value $(2.695 \mathrm{eV})$ of the $0.5 \% \mathrm{Pt}-\mathrm{CdO}$ thin film is the lowest value of all the films, while the excitation energy value $(3.670 \mathrm{eV})$ of the $2 \% \mathrm{Pt}-\mathrm{CdO}$ thin film is the highest value of all the films. This suggests that the excitation energy of the $\mathrm{CdO}$ thin film can be both reduced and increased with doping of $\mathrm{Pt}$. The excitation energy values (2.835 $\mathrm{eV}$ and $2.829 \mathrm{eV}$, respectively) of the $\mathrm{CdO}$ and $1 \% \mathrm{Pt}$ doped $\mathrm{CdO}$ thin films are lower than these values $(3.79 \mathrm{eV}$ and $3.03 \mathrm{eV}$, respectively) of the pure $\mathrm{CdO}$ and $1 \%$ B doped $\mathrm{CdO}$ thin films in the literature [80]. Similarly, the dispersion energy value $(1.648 \mathrm{eV})$ of the pure $\mathrm{CdO}$ thin film is the lowest value of all the films, while the dispersion energy value $(4.733 \mathrm{eV})$ of the $0.5 \% \mathrm{Pt}-$ $\mathrm{CdO}$ thin film is the highest value of all the films. This suggests that the dispersion energy of the $\mathrm{CdO}$ thin film can be increased with doping of $\mathrm{Pt}$. The dispersion energy value $(1.648 \mathrm{eV})$ of the $\mathrm{CdO}$ thin film is lower than that value $(7.17 \mathrm{eV})$ of the pure $\mathrm{CdO}$ thin film in the literature [80], while the dispersion energy value $(2.869 \mathrm{eV})$ of the $1 \% \mathrm{Pt}$ doped $\mathrm{CdO}$ thin film is higher than that value $(1.85 \mathrm{eV})$ of the $1 \% \mathrm{~B}$ doped $\mathrm{CdO}$ thin films in the literature [80]. As seen in Table II, the $E_{\mathrm{d}} / E_{0}$ ratio (1.756) of the $0.5 \% \mathrm{Pt}-\mathrm{CdO}$ thin film is the highest value of all the films, while the $E_{\mathrm{d}} / E_{0}$ ratio $(0.581)$ of the pure $\mathrm{CdO}$ thin film is the lowest value of all the films. This suggests that the $E_{\mathrm{d}} / E_{0}$ ratio of the $\mathrm{CdO}$ thin film can be increased with doping of $\mathrm{Pt}$.

The refractive index can be also analyzed using the following relation [94]:

$$
\frac{n_{\infty}^{2}-1}{n^{2}-1}=1-\left(\frac{\lambda_{0}}{\lambda}\right)^{2},
$$

where $n_{\infty}$ is the long wavelength refractive index and $\lambda_{0}$ is the average oscillator wavelength. The $n_{\infty}$ and $\lambda_{0}$ values of the $\mathrm{CdO}$ and $\mathrm{Pt}$ doped $\mathrm{CdO}$ thin films were obtained from the linear part of plotted $1 /\left(n^{2}-1\right)$ vs. $\lambda^{-2}$ curve (Fig. 6) and were calculated and given in Table II. As seen in Table II, the $n_{\infty}$ and $\lambda_{0}$ values of the $\mathrm{CdO}$ thin film change with doping of Pt. The $n_{\infty}$ value (1.211) of the $2 \% \mathrm{Pt}-\mathrm{CdO}$ thin film is the lowest value of all the films, while the $n_{\infty}$ value $(1.974)$ of the $0.5 \% \mathrm{Pt}-$ $\mathrm{CdO}$ thin film is the highest value of all the films. This suggests that the $n_{\infty}$ of the $\mathrm{CdO}$ thin film can be both reduced and increased with doping of Pt. The $n_{\infty}$ value (1.343) of the $\mathrm{CdO}$ thin film is lower than that value (1.7) of the pure $\mathrm{CdO}$ thin film in the literature [80], while the $n_{\infty}$ value (1.702) of the $1 \% \mathrm{Pt}$ doped $\mathrm{CdO}$ thin film is higher than that value $(1.27)$ of the $1 \% \mathrm{~B}$ doped $\mathrm{CdO}$ thin film in the literature [80]. Similarly, the $\lambda_{0}$ value $(338.4 \mathrm{~nm})$ of the $2 \% \mathrm{Pt}-\mathrm{CdO}$ thin film is the lowest value of all the films, while the $\lambda_{0}$ value $(460.9 \mathrm{~nm})$ of the $0.5 \% \mathrm{Pt}-\mathrm{CdO}$ thin film is the highest value of all the films. This suggests that the $\lambda_{0}$ value of the $\mathrm{CdO}$ thin film can be reduced and increased with doping of $\mathrm{Pt}$. The $\lambda_{0}$ values (438.1 nm and $439.1 \mathrm{~nm}$, respectively) of the $\mathrm{CdO}$ and $1 \% \mathrm{Pt}$ doped $\mathrm{CdO}$ thin films are higher than those values ( $327.7 \mathrm{~nm}$ and $409.9 \mathrm{~nm}$, respectively) of the pure $\mathrm{CdO}$ and $1 \% \mathrm{~B}$ doped $\mathrm{CdO}$ thin films in the literature [80].

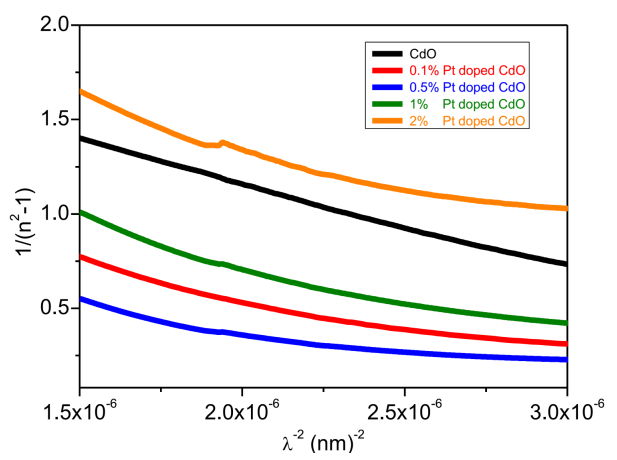

Fig. 6. The plot $1 /\left(n^{2}-1\right)$ vs. $\lambda^{-2}$ of the $\mathrm{CdO}$ and $\mathrm{Pt}$ doped CdO thin films.

Rearranging of Eq. (4) gives

$$
n^{2}-1=\frac{S_{0} \lambda_{0}^{2}}{1-\lambda_{0}^{2} / \lambda^{2}},
$$

where $S_{0}=\left(n_{\infty}^{2}-1\right) / \lambda_{0}^{2}$. The $S_{0}$ values of the $\mathrm{CdO}$ and $\mathrm{Pt}$ doped $\mathrm{CdO}$ thin films were calculated and given in Table II. As seen in Table II, the $S_{0}$ value $(1.324 \times$ $\left.10^{12} \mathrm{~m}^{-2}\right)$ of the $\mathrm{CdO}$ thin film increases with doping of Pt. The $S_{0}$ value $\left(4.074 \times 10^{12} \mathrm{~m}^{-2}\right)$ of the $\mathrm{CdO}$ thin film is lower than that value $\left(1.75 \times 10^{13} \mathrm{~m}^{-2}\right)$ of the pure $\mathrm{CdO}$ thin film in the literature [80], while the $S_{0}$ value $\left(9.838 \times 10^{12} \mathrm{~m}^{-2}\right)$ of the $1 \% \mathrm{Pt}$ doped $\mathrm{CdO}$ thin film is higher than that value $\left(3.64 \times 10^{12} \mathrm{~m}^{-2}\right)$ of the $1 \% \mathrm{~B}$ doped $\mathrm{CdO}$ thin film in the literature [80].

\subsubsection{Optical band gap properties of the $\mathrm{CdO}$ and $\mathrm{Pt}$} doped $\mathrm{CdO}$ thin films

The optical band gap of optical transitions can be obtained dependence of absorption coefficient on photon 
energy. It is evaluated that the band structure of the film obeys the rule of direct transition and in a direct band gap material; the absorption coefficient dependence on photon energy is analyzed by the following relation $[93,95]$ :

$$
\alpha=A\left(h \nu-E_{\mathrm{g}}\right)^{m},
$$

where $A$ is a constant, $h \nu$ is the photon energy, $E_{\mathrm{g}}$ is the optical band and $m$ is the parameter measuring type of band gaps.

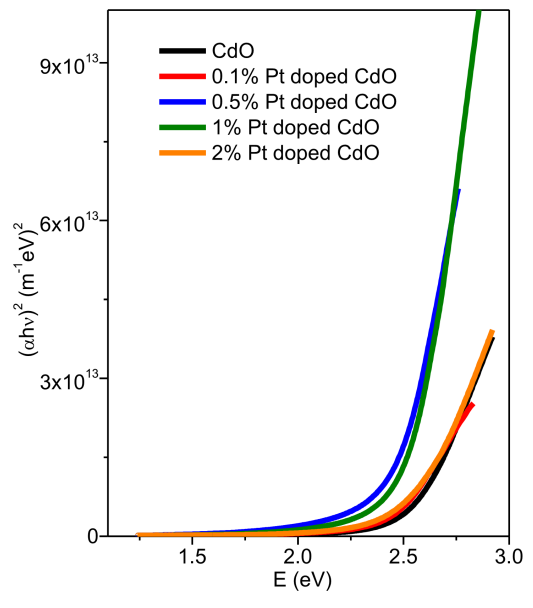

Fig. 7. The dependence of photon energy $E$ of $(\alpha h \nu)^{2}$ of the $\mathrm{CdO}$ and $\mathrm{Pt}$ doped $\mathrm{CdO}$ thin films.

To determine the optical band gap of the $\mathrm{CdO}$ and $\mathrm{Pt}$ doped $\mathrm{CdO}$ thin films, the dependence of photon energy $E$ of $(\alpha h \nu)^{2}$ of the $\mathrm{CdO}$ and $\mathrm{Pt}$ doped $\mathrm{CdO}$ thin films is shown in Fig. 7. As seen in inset of Fig. 7, there is a linear region for the direct band gap of the $\mathrm{CdO}$ and $\mathrm{Pt}$ doped $\mathrm{CdO}$ thin films.

TABLE III

The direct band gap values of the $\mathrm{CdO}$ and $\mathrm{Pt}$ doped $\mathrm{CdO}$ thin films.

\begin{tabular}{c|c}
\hline \hline Thin films & $E_{g d}[\mathrm{eV}]$ \\
\hline pure CdO & 2.524 \\
$0.1 \% \mathrm{Pt}-\mathrm{CdO}$ & 2.446 \\
$0.5 \% \mathrm{Pt}-\mathrm{CdO}$ & 2.421 \\
$1 \% \mathrm{Pt}-\mathrm{CdO}$ & 2.496 \\
$2 \% \mathrm{Pt}-\mathrm{CdO}$ & 2.506
\end{tabular}

By extrapolating the linear plot to $(\alpha h \nu)^{2}=0$, a direct energy-gap values of the $\mathrm{CdO}$ and $\mathrm{Pt}$ doped $\mathrm{CdO}$ thin films were obtained and given in Table III. As seen in Table III, the direct energy-gap values of the $\mathrm{CdO}$ thin film change with doping of Pt. The direct energy-gap value $(2.524 \mathrm{eV})$ of the $\mathrm{CdO}$ thin film is the highest value of all the films, while the direct energy-gap value $(2.421 \mathrm{eV})$ of the $0.5 \% \mathrm{Pt}-\mathrm{CdO}$ thin film is the lowest value of all the films. This suggests that the direct energy-gap of the $\mathrm{CdO}$ thin film can be decreased with doping of $\mathrm{Pt}$ and the electrical conductivity of the $\mathrm{CdO}$ thin film can be increased with convenient doping of Pt. The direct energy-gap value $(2.524 \mathrm{eV})$ of the $\mathrm{CdO}$ thin film is higher than that the values $(2.18,2.2,2.3,2.38 \mathrm{eV})$ of $\mathrm{CdO}$ film in the literature $[45-47,50,96]$. Also, the direct energy-gap value $(2.524 \mathrm{eV})$ of the $\mathrm{CdO}$ thin film is close to values $(2.6 \mathrm{eV})$ of the direct energy-gap in the literature [48].

3.2.3. Dielectric and electrical susceptibility properties of the $\mathrm{CdO}$ and $\mathrm{Pt}$ doped $\mathrm{CdO}$ thin films

The complex dielectric constant is described as

$$
\hat{\varepsilon}=\varepsilon_{1}+\mathrm{i} \varepsilon_{2}=\hat{n}^{2}=(n \pm \mathrm{i} k)^{2}=\left(n^{2}-k^{2}\right)+\mathrm{i} 2 n k, \text { (7) }
$$
where $\varepsilon_{1}$ is the real part and $\varepsilon_{2}$ is the imaginary of the dielectric constant. The imaginary and real parts of dielectric constant are given as [97]:

$$
\varepsilon_{1}=n^{2}-k^{2}
$$

and

$$
\varepsilon_{2}=2 n k,
$$

where $k=\alpha \lambda / 4 \pi$. Figure 8a,b shows the real and imaginary parts of dielectric constant dependence on photon energy, respectively. As seen in Fig. 8a, plot of the real part of dielectric constant is composed of two regions between about $1.24 \mathrm{eV}$ and $3.05 \mathrm{eV}$ which they called normal and abnormal dispersion region. The $\varepsilon_{1}$ values of the $\mathrm{CdO}$ and $\mathrm{Pt}$ doped $\mathrm{CdO}$ thin films increase with increasing photon energy (or frequency) in normal dispersion region, while the $\varepsilon_{1}$ values of the $\mathrm{CdO}$ and $\mathrm{Pt}$ doped $\mathrm{CdO}$ thin films decrease with increasing photon energy (or frequency) in abnormal dispersion region. As seen in Fig. 8a, the $\varepsilon_{1}$ values of the $\mathrm{CdO}$ thin film change with doping of $\mathrm{Pt}$ and in between about $1.24 \mathrm{eV}$ and $3.05 \mathrm{eV}$ region, the $\varepsilon_{1}$ of the $0.5 \% \mathrm{Pt}-\mathrm{CdO}$ thin film is the highest value, while the $\varepsilon_{1}$ of the $2 \% \mathrm{Pt}-\mathrm{CdO}$ thin film is the lowest value of all the films. This suggests that the $\varepsilon_{1}$ of the $\mathrm{CdO}$ thin film can be both reduced and increased with doping of Pt. As seen in Fig. 8b, the imaginary part $\left(\varepsilon_{2}\right)$ of dielectric constant increases with $E$ until about $4.55 \mathrm{eV}$, then it decreases with increasing photon energy $(E)$. As seen in Fig. 8a,b, the real parts of the dielectric constant of the $\mathrm{CdO}$ and $\mathrm{Pt}$ doped $\mathrm{CdO}$ thin films are higher than that of imaginary parts of the dielectric constant.

The susceptibility associated with electron transitions from band $i$ to band $j$ is expressed as [98]:

$$
\chi_{\nu}=\frac{e^{2}}{4 \pi^{2} m} \sum_{k} \frac{f_{j i k}}{\nu_{j i k}^{2}-\nu^{2}},
$$

where $k$ is the wave number vector, $h \nu_{j i k}$ is the energy difference between the state $k$ in band $i$ and the state $k$ in band $j$ and $f_{j i k}$ is the oscillator strength for this transition. The electrical susceptibility due to the intraband transitions of free carriers can be obtained from the optical constants and it is determined as [99]:

$$
\chi_{\mathrm{c}}=\frac{1}{4 \pi}\left(n^{2}-k^{2}-\varepsilon_{0}\right),
$$

where $\varepsilon_{0}$ is the dielectric constant in the absence of any contribution from free carriers. The electric susceptibility of the $\mathrm{CdO}$ and $\mathrm{Pt}$ doped $\mathrm{CdO}$ thin films dependence of photon energy is shown in Fig. 9. As seen in Fig. 9, the electric susceptibility $\left(\chi_{\mathrm{c}}\right)$ of the $\mathrm{CdO}$ and Pt doped 


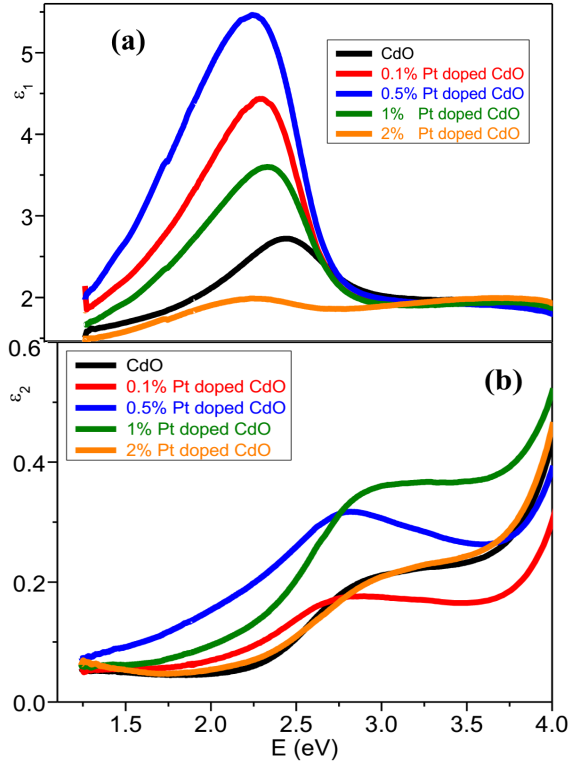

Fig. 8. The (a) real and (b) imaginary parts of dielectric constant of the $\mathrm{CdO}$ and $\mathrm{Pt}$ doped $\mathrm{CdO}$ thin films dependence on photon energy.

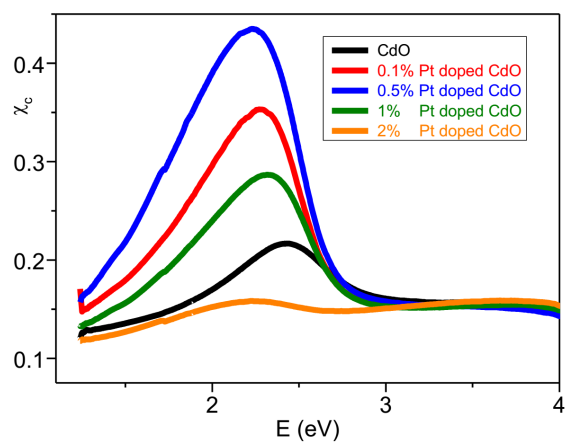

Fig. 9. The electric susceptibility of the $\mathrm{CdO}$ and $\mathrm{Pt}$ doped $\mathrm{CdO}$ thin films dependence of photon energy.

$\mathrm{CdO}$ thin films is composed of two regions for between about $1.24 \mathrm{eV}$ and $3.05 \mathrm{eV}$ and the $\chi_{\mathrm{c}}$ values of the $\mathrm{CdO}$ thin film change with doping of $\mathrm{Pt}$ and in between about $1.24 \mathrm{eV}$ and $3.05 \mathrm{eV}$ region. The $\chi_{\mathrm{c}}$ of the $0.5 \% \mathrm{Pt}-\mathrm{CdO}$ thin film is the highest value, while the $\chi_{\mathrm{c}}$ of the $2 \% \mathrm{Pt}-$ $\mathrm{CdO}$ thin film is the lowest value of all the films. This suggests that the $\chi_{\mathrm{c}}$ of the $\mathrm{CdO}$ thin film can be both reduced and increased with doping of $\mathrm{Pt}$.

\subsubsection{Optical conductivity properties of the $\mathrm{CdO}$ and $\mathrm{Pt}$} doped CdO thin films

The optical properties of the $\mathrm{CdO}$ and $\mathrm{Pt}$ doped $\mathrm{CdO}$ thin films can be analyzed by a complex optical conductivity $[93,100]$ :

$$
\sigma(\omega)=\sigma_{1}(\omega)+\mathrm{i} \sigma_{2}(\omega),
$$

where $\sigma_{1}$ is the real part of conductivity and $\sigma_{2}$ is the imaginary part of conductivity.

The real part and imaginary parts of the optical conductivity of the $\mathrm{CdO}$ and $\mathrm{Pt}$ doped $\mathrm{CdO}$ thin films are shown in Fig. 10a,b, respectively. As seen in Fig. 10a, the

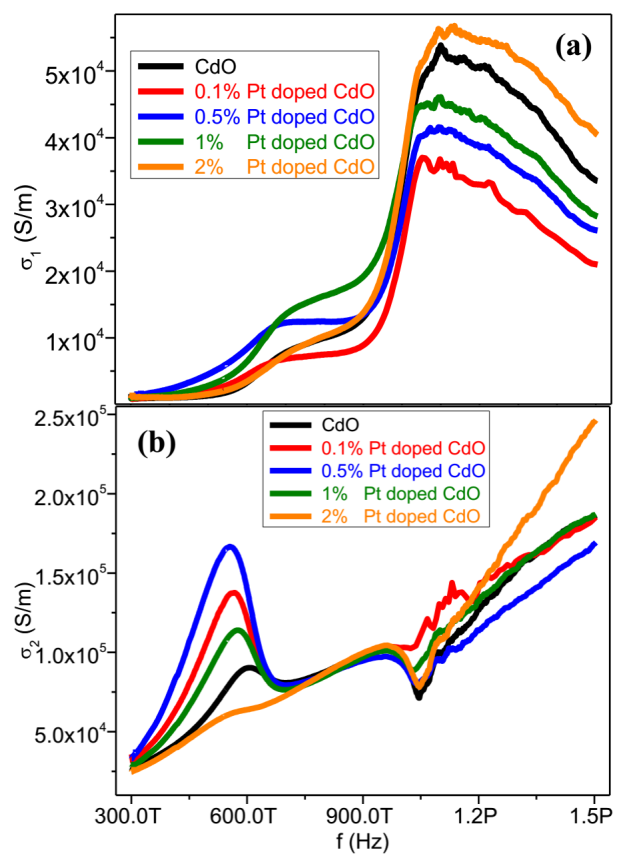

Fig. 10. The (b) real and (b) imaginary parts of the optical conductivity of the CdO and Pt doped CdO thin films dependence on frequency.

real part $\left(\sigma_{1}\right)$ of the optical conductivity increases with frequency until about $1.09 \mathrm{THz}$, then it decreases with increasing frequency. As seen in Fig. 10b, there is a peak for between about $253 \mathrm{THz}$ and $700 \mathrm{THz}$ and the $\sigma_{2}$ values of the $\mathrm{CdO}$ thin film change with doping of $\mathrm{Pt}$ and in between about $253 \mathrm{THz}$ and $700 \mathrm{THz}$ region, the $\sigma_{2}$ of the $0.5 \% \mathrm{Pt}-\mathrm{CdO}$ thin film is the highest value, while the $\sigma_{2}$ of the $2 \% \mathrm{Pt}-\mathrm{CdO}$ thin film is the lowest value of all the films. This suggests that the $\sigma_{2}$ of the $\mathrm{CdO}$ thin film can be both reduced and increased with doping of Pt. As seen in Fig. 10a,b, the imaginary parts of the optical conductivity of the $\mathrm{CdO}$ and $\mathrm{Pt}$ doped $\mathrm{CdO}$ thin films are higher than that of the real parts of the optical conductivity.

\section{Conclusions}

The $\mathrm{CdO}$ and $\mathrm{Pt}$ doped $\mathrm{CdO}$ thin films were formed from small crystal grains with an almost homogeneous distribution. It was observed that the small crystal grain size of the $\mathrm{CdO}$ thin film increases with doping of $\mathrm{Pt}$. Therefore, the grain size and the surface roughness of the co-doped films could be controlled. The absorption band edge values of the $\mathrm{CdO}$ and $\mathrm{Pt}$ doped $\mathrm{CdO}$ thin films shifted from 2.264 to $1.948 \mathrm{eV}$ with the doping of $\mathrm{Pt}$. The absorption band edge of the $\mathrm{CdO}$ thin film decreased with doping of Pt. The plot of refractive index is composed of two regions so-called abnormal and normal dispersion. The $n$ values of the $\mathrm{CdO}$ and $\mathrm{Pt}$ doped $\mathrm{CdO}$ thin films increased with increasing $\lambda$ in abnormal dispersion region, while the refractive index $(n)$ values of the $\mathrm{CdO}$ and $\mathrm{Pt}$ doped $\mathrm{CdO}$ thin films decreased with increasing wavelength in normal dispersion region. The refractive index of the $\mathrm{CdO}$ thin film can be both reduced 
and increased with doping of Pt. This is a very significant improvement for optical applications. The $n_{\infty}, \lambda_{0}$, $\varepsilon_{1}, \chi_{\mathrm{c}}, \sigma_{2}$ and excitation of the $\mathrm{CdO}$ thin film can be both reduced and increased with doping of Pt. The dispersion energy and $E_{\mathrm{d}} / E_{0}$ ratio of the $\mathrm{CdO}$ thin film can be increased with doping of Pt. Similarly, the $S_{0}$ value $\left(4.074 \times 10^{12} \mathrm{~m}^{-2}\right)$ of the $\mathrm{CdO}$ thin film increased with doping of Pt. The direct energy-gap of the $\mathrm{CdO}$ thin film can be decreased with doping of $\mathrm{Pt}$ and the electrical conductivity of the $\mathrm{CdO}$ thin film can be increased with convenient doping of $\mathrm{Pt}$. The plot of the real part of dielectric constant was composed of two regions for between about $1.24 \mathrm{eV}$ and $3.05 \mathrm{eV}$ which they called normal and abnormal dispersion region. There was a peak for between about $253 \mathrm{THz}$ and $700 \mathrm{THz}$ and the $\sigma_{2}$ values of the $\mathrm{CdO}$ thin film changed with doping of $\mathrm{Pt}$ and in between about $253 \mathrm{THz}$ and $700 \mathrm{THz}$ region.

\section{Acknowledgments}

The authors gratefully acknowledge and thank the King Abdulaziz University (KAU), Saudi Arabia, for the research group "Advances in composites, synthesis and applications". This work is a result of international collaboration of the group with Prof. F. Yakuphanoglu.

\section{References}

[1] S. Kose, F. Atay, V. Bilgin, I. Akyuz, Int. J. Hydrogen Energy 34, 5260 (2009).

[2] L. Zhao, J. Lian, Y. Liu, Q. Jiang, Appl. Surf. Sci. 252, 8451 (2006).

[3] F.O. Adurodija, L. Semple, R. Bruning, Thin Solid Films 492, 153 (2005).

[4] I. Saadeddin, B. Pecquenard, J.P. Manaud, R. Decourt, C. Labrugère, T. Buffeteau, Appl. Surf. Sci. 253, 5240 (2007).

[5] C.H. Bhosale, A.V. Kambale, A.V. Kokate, K.Y. Rajpure, Mater. Sci. Eng. B 122, 67 (2005).

[6] B.G. Lewis, D.C. Paine, MRS Bull. 25, 22 (2000).

[7] B. Saha, S. Das, K.K. Chattopadhyay, Sol. En. Mater. Solar Cells 91, 1692 (2007).

[8] K.L. Chopra, S.R. Das, Thin Film Solar Cells, Plenum Press, New York 1983, Ch. 3, p. 346.

[9] G. Phatak, R. Lal, Thin Solid Films 245, 17 (1994).

[10] A. Verkey, A.F. Fort, Thin Solid Films 239, 211 (1994).

[11] A.J. Freeman, K.R. Poeppelmeier, T.O. Mason, R.P.H. Chang, T.J. Marks, MRS Bull. 25, 45 (2000).

[12] C. Wang, V. Cimalla, G. Cherkashinin, H. Romanus, M. Ali, O. Ambacher, Thin Solid Films 515, 2921 (2007).

[13] K.L. Chopra, S. Major, D.K. Pandya, Thin Solid Films 102, 1 (1983).

[14] D.M. Mattox, Thin Solid Films 204, 25 (1991).

[15] S. Gao, Y. Zhao, P. Gou, N. Chen, Y. Xie, Nanotechnology 14, 538 (2003).

[16] A.N. Banerjee, K.K. Chattopadhyay, J. Appl. Phys. 97, 084308 (2005).

[17] S. Sheng, G. Fang, C. Li, Z. Chen, S. Ma, L. Fang, X. Zhao, Semicond. Sci. Technol. 21, 586 (2006).
[18] Y.X. Huang, Z.G. Ji, C. Chen, Appl. Surf. Sci. 253, 4819 (2007)

[19] A.K. Kulkarni, K.H. Schulz, T.S. Lim, B. Khan, Thin Solid Films 345, 273 (1999).

[20] N. Ito, Y. Sato, P.K. Song, A. Kaijio, K. Inoue, Y. Shigesato, Thin Solid Films 496, 99 (2006).

[21] J.T. Lim, C.H. Jeong, A. Vozny, J.H. Lee, M.S. Kim, G.Y. Yeom, Surf. Coat. Technol. 201, 5358 (2007).

[22] H. Kim, C.M. Gilmore, A. Pique, J.S. Horwitz, H. Mattoussi, H. Murata, Z.H. Kafafi, D.B. Chrisey, J. Appl. Phys. 11, 6451 (1999).

[23] J.A.A. Selvan, A.E. Delahoy, S. Guo, Y.-M. Li, Sol. En. Mater. Sol. Cells 90, 3371 (2006).

[24] Z. Zhao, D.L. Morel, C.S. Ferekides, Thin Solid Films 413, 203 (2002).

[25] L.M. Su, N. Grote, F. Schmitt, Electron. Lett. 20, 716 (1984).

[26] O. Gomez Daza, A.A.-C. Readigos, J. Campos, M.T.S. Nair, P.K. Nair, Mod. Phys. Lett. B 17, 609 (2001).

[27] B.J. Zheng, J.S. Lian, L. Zhao, Q. Jiang, Appl. Surf. Sci. 256, 2910 (2010).

[28] F. Yakuphanoglu, M. Caglar, Y. Caglar, S. Ilican, J. Alloys Comp. 506, 188 (2010).

[29] C.V. Suryanarayana, Bull. Electrochem. 2, 57 (1986).

[30] M.D. Uplane, P.N. Kshirsagar, B.J. Lokhande, C.H. Bhosale, Mater. Chem. Phys. 8630, 1 (1999).

[31] L.M. Peter, J. Electroanal. Chem. 98, 49 (1979).

[32] Y. Yang, L. Wang, H. Yan, S. Jin, T.J. Marksa, S. Li, Appl. Phys. Lett. 89, 051116 (2006).

[33] M. Yan, M. Lane, C.R. Kannewurf, R.P.H. Chang, Appl. Phys. Lett. 78, 2342 (2001).

[34] B.J. Zheng, J.S. Lian, L. Zhao, Q. Jiang, Vacuum 85, 861 (2011).

[35] T.J. Coutts, D.L. Young, X. Li, W.P. Mulligan, X. Wu, J. Vac. Sci. Technol. A 18, 2646 (2000).

[36] A.W. Metz, J.R. Ireland, J.G. Zheng, R. Lobo, Y. Yang, J. Ni, C.L. Stern, C.V.P. Dravid, N. Bontempz, C.R. Kannewurf, K.R. Poeppelmeier, T.J. Marks, J. Am. Chem. Soc. 126, 8477 (2004).

[37] R. Kumaravel, S. Menaka, S. Regina Mary Snega, K. Ramamurthi, K. Jeganathan, Mater. Chem. Phys. 122, 444 (2010).

[38] J.C. Manifacier, Thin Solid Films 90, 297 (1982).

[39] B. Saha, R. Thapa, K.K. Chattopadhyay, Solid State Commun. 145, 33 (2008).

[40] P.H. Jefferson, S.A. Hatfield, T.D. Veal, P.D.C. King, C.F. McConville, J. Zuniga-Perez, V. Munoz-Sanjose, Appl. Phys. Lett. 92, 022101 (2008).

[41] Y.S. Choi, C.G. Lee, S.M. Cho, Thin Solid Films 289, 153 (1996).

[42] J.S. Cruz, G.T. Delgado, R.C. Perez, S.J. Sandoval, O.J. Sandoval, C.I.Z. Romero, J.M. Marin, O.Z. Angel, Thin Solid Films 493, 83 (2005).

[43] R.M. Navarro, F. del Valle, J.L.G. Fierro, Int. J. Hydrog. En. 33, 4265 (2008).

[44] A.A. Dakhel, Semicond. Sci. Technol. 23, 055017 (2008). 
[45] R. Kondo, H. Okhimura, Y. Sakai, Jpn. J. Appl. Phys. 10, 1547 (1971).

[46] S. Aksoy, Y. Caglar, S. Ilican, M. Caglar, Int. J. Hydrog. En. 34, 5191 (2009).

[47] M. Ortega, G. Santana, A. Morales-Acevedo, Solid State Electron. 44, 1765 (2000).

[48] D.M.C. Galicia, R.C. Perez, O.J. Sandoval, S.J. Sandoval, G.T. Delgado, C.I.Z. Romero, Thin Solid Films 371, 105 (2000).

[49] R.J. Deokate, S.V. Salunkhe, G.L. Agawane, B.S. Pawar, S.M. Pawar, K.Y. Rajpure, A.V. Moholkar, J.H. Kim, J. Alloys Comp. 496, 357 (2010).

[50] H. Finnkenrath, H. Kohler, M. Lochmann, Z.F. Angew, PhysicA 21, 512 (1966).

[51] K. Maschke, U. Rossler, Phys. Status Solidi 28, 577 (1968).

[52] S. Tewari, Solid State Commun. 12, 437 (1973).

[53] A. Breeze, P.G. Perkins, Solid State Commun. 13, 1031 (1973).

[54] A.A. Dakhel, Solar Energy 82, 513 (2008).

[55] J. Arthur Nozik, Nano Lett. 10, 2735 (2010).

[56] V. Prashant Kamat, J. Phys. Chem. C 112, 18737 (2008).

[57] C.C. Vidyasagar, Y. Arthoba Naik, T.G. Venkatesh, R. Viswanatha, Powder Technol. 214, 337 (2011).

[58] M.A. Flores, R. Castanedo, G. Torres, O. Zelaya, Sol. En. Mater. Sol. Cells 93, 28 (2009).

[59] J.S. Cruz, G.T. Delgado, R.C. Perez, S.J. Sandoval, J.M. Marin, O.Z. Angel, Sol. En. Mater. Sol. Cells 90, 2272 (2006).

[60] C.S. Ferekides, R. Mamazza, U. Balasubramanian, D.L. Morel, Thin Solid Films 480, 224 (2005).

[61] C. Xiangfeng, Mater. Res. Bull. 38, 1705 (2003).

[62] M. Ristic, S. Popovic, S. Music, Mater. Lett. 58, 2494 (2004)

[63] T.L. Chu, S.S. Chu, J. Electron. Mater. 19, 1003 (1990).

[64] R.S. Mane, S.H. Han, Electrochem. Commun. 7, 205 (2005).

[65] F.Z. Wang, Z.Z. Ye, D.W. Ma, L.P. Zhu, F. Zhuge, H.P. He, Appl. Phys. Lett. 87, 1443101 (2005).

[66] F.Z. Wang, H.P. He, Z.Z. Ye, L.P. Zhu, J. Appl. Phys. 8, 084301 (2005).

[67] A. Wang, J.R. Babcock, N.L. Edleman, A.W. Metz, M.A. Lane, R. Asahi, V.P. Dravid, C.R. Kannewurf, Proc. Natl. Acad. Sci. 98, 7113 (2001)

[68] B. Li, L. Zeng, F. Zhang, Phys. Status Solidi A 201 , 960 (2004).

[69] H.M. Ali, H.A. Mohamed, M.M. Wakkad, M.F. Hasaneen, Thin Solid Films 515, 3024 (2007).

[70] J. Santos Cruz, G. Torres Delgado, R. Castanedo Pérez, C.I. Zúñiga Romero, O. Zelaya Angel, Thin Solid Films 515, 5381 (2007).

[71] P.K. Ghosh, R. Maity, K.K. Chattopadhyay, Sol. En. Mater. Sol. Cells 81, 279 (2004).
[72] C. Aydın, H.M. El-Nasser, F. Yakuphanoglu, I.S. Yahia, M. Aksoy, J. Alloys Comp. 509, 854 (2011).

[73] B.K. Sonawane, Vrushali Shelke, M.P. Bhole, D.S. Patil, J. Phys. Chem. Solids 72, 1442 (2011).

[74] R.K. Gupta, F. Yakuphanoglu, F.M. Amanullah, Physica E 43, 1666 (2011).

[75] Y. Yang, S.J. Shu, J.E. Medvedeva, J.R. Ireland, A.W. Metz, Ni. Jun, M.C. Hersam, A.J. Freeman, T.J. Marks, J. Am. Chem. Soc. 127, 8796 (2005).

[76] A.A. Dakhel, J. Alloys Comp. 475, 51 (2009).

[77] R.S. De Biasi, M.L.N. Grillo, J. Alloys Comp. 485, 26 (2009).

[78] R. Maity, K.K. Chattopadhyay, Sol. En. Mater. Sol. Cells 90, 597 (2006)

[79] R.J. Deokate, S.M. Pawar, A.V. Moholkar, V.S. Sawant, C.A. Pawar, C.H. Bhosale, K.Y. Rajpure, Appl. Surf. Sci. 254, 2187 (2008).

[80] F. Yakuphanoglu, Solar Energy 85, 2704 (2011).

[81] A.A. Dakhel, J. Mater. Sci. 46, 1455 (2011).

[82] A.A. Dakhel, Sol. Energy 83, 934 (2009).

[83] R.K. Gupta, K. Ghosh, R. Patel, P.K. Kahol, Appl. Surf. Sci. 255, 6252 (2009).

[84] R.K. Gupta, K. Ghosh, R. Patel, S.R. Mishra, P.K. Kahol, Mater. Lett. 62, 4103 (2008).

[85] R.K. Gupta, K. Ghosh, R. Patel, S.R. Mishra, P.K. Kahol, Appl. Surf. Sci. 254, 5868 (2008).

[86] R.K. Gupta, K. Ghosh, R. Patel, S.R. Mishra, P.K. Kahol, Curr. Appl. Phys. 9, 673 (2009).

[87] E. Martin, M. Yan, M. Lane, J. Ireland, C. Kannewurf, R.H. Chang, Thin Solid Films 461, 309 (2004).

[88] M. Yan, M. Lane, C.R. Kannewurf, R.P.H. Chang, Appl. Phys. Lett. 78, 02342 (2001).

[89] E. Burstein, Phys. Rev. 93, 632 (1954).

[90] F. Yakuphanoglu, Appl. Surf. Sci. 257, 1413 (2010).

[91] A.A. Dakhel, Thin Solid Films 517, 886 (2008).

[92] R.J. Deokate, S.V. Salunkhe, G.L. Agawane, B.S. Pawar, S.M. Pawar, K.Y. Rajpure, A.V. Moholkar, J.H. Kim, J. Alloys Comp. 496, 357 (2010).

[93] Optical Properties of Solids, Ed. F. Abeles, NorthHolland, Amsterdam 1972.

[94] M. DiDomenico, S.H. Wemple, J. Appl. Phys. 40, 720 (1969).

[95] B. Gunduz, F. Yakuphanoglu, Sensors Actuat. A 178, 141 (2012).

[96] G. Yogeeswaran, C.R. Chenthamarakshan, A. Seshadri, N.R. de Tacconi, K. Rajeshwar, Thin Solid Films 515, 2464 (2006).

[97] A.K. Wolaton, T.S. Moss, Proc. R. Soc. 81, 5091 (1963).

[98] W.G. Spitzer, H.Y. Fan, Phys. Rev. 106, 882 (1957).

[99] J. Taue, in: Optical Properties of Solids, Ed. F. Abeles, North-Holland, Amsterdam 1972.

[100] J.N. Hodgson, Optical Absorption and Dispersion in Solids, Chapman and Hall, London 1970. 